\title{
Interest Representation and the Transformation of the Chinese Communist Party
}

\author{
ZHENG YONGNIAN
}

\begin{abstract}
At the 80th anniversary celebration of the Chinese Communist Party (CCP) on 1 July 2001, Jiang Zemin called on the party to admit into its ranks of 'outstanding social elements' of private entrepreneurs, professionals, technical and managerial personnel from non-state firms and MNCs. Party ideologues, however, have raised a great hue and cry. In order to establish his political legacy, the CCP leadership has intensified the campaign to educate its cadres and members. Reform and development have bourgeoisified and benefited many party members and cadres. Jiang's public support of the capitalists is not going against the tide but is a recognition of reality instead. In fact, to continue to grow and expand, the party must embrace the better educated and the most enterprising in society. The capitalists within the party will certainly be catalysts to quicken the transformation of the party. In its attempt to admit capitalists, has the CCP unknowingly let in the Trojan horse? Jiang Zemin's original aim may have been to strengthen the party-state by broadening its social base. And as the party metamorphoses, perhaps into a kind of social democratic party, Jiang will be favourably judged for paving the way for such a metamorphosis. Nevertheless, it is not an easy transition: insurmountable difficulties lie ahead for the party leadership.
\end{abstract}

\section{Introduction}

In his controversial speech celebrating the 80th anniversary of the Chinese Communist Party (CCP) on 1 July 2001, Jiang Zemin called on the party to admit those 'outstanding elements' of society such as private entrepreneurs, professionals, technical and managerial personnel from various non-state sectors, including those employed by MNCs. ${ }^{1}$ According to Jiang, these are people who can also make a positive contribution to the rebuilding of China's socialism, and should therefore not be excluded from the party. Whether they are politically progressive (xianjin) or backward (luohou) should not be judged purely on whether they are property-owning classes.

'Private entrepreneurs' - actually an official euphemism for 'capitalists' or 'private businessmen' - were hitherto publicly barred from the party. The proposed membership relaxation has generated much en- 
thusiasm from many private businessmen wanting to join the party. Immediately after Jiang's speech, more than '100,000 private entrepreneurs' were reported to have submitted applications to join the party. The party's organization department (headed by Zeng Qinghong) is planning to recruit 200,000 private entrepreneurs before the 16th Congress in September 2002. ${ }^{2}$

Traditionally, the CCP was supposed to represent the interests of only five major groups, i.e., workers, peasants, intellectuals, members of the PLA (People's Liberation Army), and government officials and cadres. The majority of the original rank and file of the party was basically drawn from the 'proletariat' background. In championing the causes of capitalists, Jiang's initiative has been hailed by supporters as a theoretical breakthrough, throwing off the party's old dogmas, particularly the shackle of class. At the same time, for Jiang as General Secretary to openly embrace capitalists - the antithesis of the proletariat class - amounts to dropping an ideological bombshell on the conservative wing of the party. Naturally, the party's ideologues have raised a great hue and cry. The strength of the opposition from these party diehards seems to have taken Jiang by surprise.

The opposition came into the open with the publication on the Chinese Internet of a widely circulated Wanyan-shu or 'a petition of tenthousand words,' attributed to a group of conservative party veterans led by long-time leftist critic Deng Liqun. Prior to Jiang's 'July 1 speech,' several provincial party leaders, such as deputy party secretary of Jilin Province Lin Yanzhi, had already spoken out against Jiang's scheme. ${ }^{3}$ Zhang Dejiang, party secretary of Zhejiang Provincial Committee of the CCP, had also strongly argued that private entrepreneurs should not be allowed to join the CCP. ${ }^{4}$ Zhejiang is among the few provinces in China where the private sector has made rapid inroads and has played an increasingly important role in the local economy and even politics. Zhang's strong opposition suggested that there was no consensus within the party leadership on the political role of the private sector. Indeed, the arguments presented by Lin and Zhang are representative of and are popular among old-style leftists. In brief, apart from being accused of breaching the party's cardinal principle by courting members of the exploitative class, Jiang was blamed for his failure to address the burning issues of growing unemployment and widening income disparities, and his failure to hold formal consultations within the party before making the announcement. 
In response, Jiang quickly ordered the closure of the two 'theoretical' (i.e. ideological) magazines, Zhenli de zhuiqiu [Seeking Truth] and Zhongliu [The Central Pillar], which were well-known mouthpieces of the leftists. ${ }^{5}$ Subsequently, some leftist websites were also shut down. ${ }^{6}$ Since then party cadres throughout China, including officers of the PLA, have been instructed to hold study sessions of Jiang's 'July 1 Speech. ${ }^{17}$

Not too long ago, the CCP had continued to proclaim that its ultimate goal was to eliminate capitalism; and all forms of politically and ideologically incorrect 'elements' such as 'private entrepreneurs' or capitalists were not allowed to exist in the party. Although it is still not certain today what political role the rising new capitalist class will play, the party seems to have begun its transformation from traditional Marxism and Leninism to something else. This paper attempts to examine this transformation by employing the concept 'interest' based on Albert Hirschman's definition. The paper is divided into sections. The first section discusses the concept 'interest.' The second section examines the rise of an interest-based social order and its impact on Chinese politics. The third section highlights how the party leadership has adjusted the party to accommodate a rising interest-based social order. Finally, I shall discuss what difficulties lie ahead in the process of transformation.

\section{'Interest'}

'Interest' has been a fundamental force that motivates the action of the actor. The concept of 'interest' used here is drawn largely from Hirschman's definition. ${ }^{8}$ 'Interest' motivates action, but actors define 'interest' differently, including interest in honour, glory, self-respect, in an afterlife, in economic advantage, etc. ${ }^{9}$ Regardless of the various definitions of 'interest,' this paper regards 'interest' as a 'methodical pursuit and accumulation of private wealth. ${ }^{10}$ According to Hirschman, an interest-propelled action is characterized by self-centredness, that is, 'predominant attention of the actor to the consequences of any contemplated action for himself,' and rational calculation, that is, 'a systematic attempt at evaluating prospective costs, benefits, satisfactions, and the like. ${ }^{11}$

There are political benefits of an interest-based social order. First of all, an interest-based social order is more governable than one based on other non-interest-based factors, such as various forms of passion, since interest-guided individual behaviour is more predictable than a passion-guided act. As Hirschman noted, 'A world where people methodically pursue their private interests was ... far more predictable, and hence more governable, than one where the citizens are vying with each 
other for honor and glory' (emphasis original). ${ }^{12}$ Second, in an interestbased social order, individual behaviour is expected to be stable and continuous. When individuals pursue 'single-mindedly material interests,' their behaviour will not experience any turbulent change.

Third, economic expansion and the coming of an interest-based social order can make individual behaviour increasingly peaceful. In what Hirschman called the French thesis of the doux commerce, 'commerce was often regarded as a powerful civilizing agent diffusing prudence, probity, and similar virtues within and among trading societies. ${ }^{13}$ This theme was expressed by Montesquieu in the Spirit of Laws when he declared,

[I]t is almost a general rule that wherever manners are gentle there is commerce; and wherever there is commerce, manners are gentle. [C]ommerce ... polishes and softens barbaric ways as we can see everyday. ${ }^{14}$

Fourth and even more relevant to this paper, the principle of doux commerce is applicable not only to democracy, but also to other types of regime such as monarchy and despotism. Economic expansion can soften a regime's use of coercion. It can even lead to regime changes by eliminating arbitrary and authoritarian decision-making by the sovereign. For Montesquieu, with the rise of specific new economic institutions resulting from economic expansion, the state will be largely deprived of its traditional power such as the power 'to seize property and to debase the currency at will.' For Steuart, 'it is rather the overall complexity and vulnerability of the 'modern economy' that make arbitrary decisions and interferences unthinkable - that is, exorbitantly costly and disruptive. ${ }^{15}$ Furthermore, economic expansion can also empower the people. According to Millar, the advance of commerce and manufacturing gives rise to a general diffusion of the spirit of liberty. This is so because it enhances the ability of certain social groups to resort to collective action against oppression and mismanagement. ${ }^{16}$

Finally, many scholars have argued that the economic benefits from economic expansion will make the state soften its rule over economic activities and respect people's basic economic freedom. Smith argued that economic expansion and individuals' pursuit of wealth and interest could lead to a spontaneous social order. According to him, market exchange can produce a 'natural progress of things toward improvement' because it induces individuals to consume and produce in rational ways. Free market exchange thus can ensure that the consumer is 'led by an invisible hand to promote an end which was no part of his intention. ${ }^{17}$ In other words, the market generates a 'public interest' that encompasses national wealth, a non-coercive society, and the freedom 
to choose and co-operate that emerges when individuals have the option and incentive to make rational choices. ${ }^{18}$

The logic behind the transformation of the CCP is based on the simple notion of preserving its 'interest.' It is all these advantages of 'interest' defined above that have led the Chinese leadership to justify a market economy and capitalistic development and allow capitalists to join the party.

\section{From 'Ideology' to 'Interest'}

In the pre-reform era, China can be regarded as an ideologically and politically constructed society based on the concept of 'class.' It was organized in accordance with major political leaders' perceptions of what a society should be and realized by forceful organizational weapons. As Schurmann correctly pointed out in the 1960s, 'Communist China is like a vast building made of different kinds of brick and stone. However it was put together, it stands. What holds it together is ideology and organization. ${ }^{19}$

The leadership under Mao Zedong initiated various political experiments, especially during the Cultural Revolution from 1966 to 1976, to reorganize China, according to Mao's own utopian ideals of what society should be like. Whatever Mao did, his aim was to destroy all possible private space and politicize the Chinese society. Totalitarian state power penetrated every corner of society and coercive institutional mechanisms were used to eliminate private space and manage public space. ${ }^{20}$

The household registration ( $h u k o u$ ) system was used to control population movement and bind people to their place of birth and work. Since without a household registration booklet, no one could obtain food, clothing, housing, employment, schooling for children or the right to marry or enlist in the army, the system created a spatial hierarchy of urban places, priority of urban over rural areas, and where large cities took precedence over smaller ones in terms of the allocation of state resources. ${ }^{21}$ A related institution for controlling population was the work unit (danwei) system, in which the party-state implemented ideological indoctrination and administrative disciplining such as warning, public criticism and negative records in the dossier. ${ }^{22}$ The danwei system was also a mechanism in which the party-state solicited political compliance and allegiance from individual citizens by providing them with economic and social security such as inexpensive housing, free medical care, generous retirement pensions, and a wide range of subsidies covering virtually every household need from transportation to nutrition. 
Furthermore, enormous mass organizations were created in order to mobilize millions of people to implement public policies, and to achieve the party's and even Mao's personal purposes. All these organizations were administrated and monitored by the party-state and were used to organize youths, workers, women and other social groups into bodies resembling 'a conscription society. ${ }^{123}$ Meanwhile, the party-state banned all functional organizations, which were regarded or even suspected to be 'counter-revolutionary.' All autonomous and independent organizations were prohibited.

A highly organized and politicized society, together with a planned economy, enabled the party-state to mobilize numerous social groups into the political arena, and thus created new power resources within the Chinese society to implement profound tasks of social engineering such as land reform, collectivization and nationalization of business and commerce. Nevertheless, over time, the reach of the party-state was shortened. As Shue has pointed out, the highly organized and efficacious party-state gradually degenerated into a regime obsessed with ideology and lacking almost any genuine social base beyond its partystate apparatus. No wonder then that it becomes increasingly difficult to govern either legitimately or effectively. ${ }^{24}$

In the late 1970s, the Deng Xiaoping leadership began to shift its emphasis to economics as a way of reorganizing the country. ${ }^{25}$ In the 1980s, China achieved high rates of economic growth by expanding its market space. ${ }^{26}$ But it was only after Deng's southern tour (nanxun) in 1992 that the Chinese leadership legitimized capitalism as a way of promoting economic expansion.

Why was the CCP not able to legitimize capitalism in the 1980s? Capitalism could have been legitimized in that period. After the bitter and uncertain 30 years of experimentation following 1949, many leaders realized that learning from capitalism conforms to historical necessity, and capitalism is a stage that cannot be skipped on the way to socialism. Although the party had an idea of the nineteenth-century capitalism from which Marx drew inspiration, the reform and open-door policy enabled party cadres and government officials to see what had happened to capitalism recently from China's neighbouring countries, especially the four little dragons, i.e., Hong Kong, Taiwan, Singapore and South Korea, in addition to Japan and the United States. From all these countries, the leadership saw how capitalism had helped raise the standard of living of the vast majority of the people there, and enhanced their status in international arenas, which were goals that the CCP had 
fought for since its establishment. The impact of the four little dragons on China's leaders should not be underestimated since the experiences of Hong Kong, Taiwan and Singapore showed that Chinese culture was not a barrier but a catalyst to economic growth. ${ }^{27}$ The leaders realized what was important was not cultural but institutional factors, and if the country wanted to achieve rapid economic growth, its economic system had to be overhauled. This was the motivation behind the decision of the leadership to implement economic reforms. Many social groups, especially young intellectuals, advocated publicly for capitalism, genuinely believing that capitalism could pave the way for China to grow into a strong and affluent nation. Spurring the country on was the capitalist West, which was quite friendly to China in the 1980s, as they believed China's market-oriented economic reform and open-door policy would eventually lead to two transformations, that is, from a planned economy to a free market system, and from political authoritarianism to democracy.

However, in that decade, the Chinese revolutionary leaders had quite different perceptions of the market economy and capitalism..$^{28}$ While at the practical level they did not oppose carrying out different forms of capitalistic experiment, ideologically, they were unwilling to legitimize capitalism. ${ }^{29}$ It was only after they saw that market economy did not harm the socialist system which they had fought for that they became willing to recognize its legitimacy. This can be seen from changes in the official definition of China's economic system. At the CCP's 12th Congress in 1982, the leadership defined the country's economic system as one in which the 'planned economy is the main pillar and market economy a supplementary element.' The market economy failed to gain theoretical legitimacy then. Five years later in 1987, at the 13th Congress, the leadership defined the economic system as one 'combining planned and market economies'; and here the market economy gained an ideological status equal to that of the planned economy. However, with the coming and in the aftermath of the 1989 pro-democracy movement, capitalism came under serious attack. Conservative leaders regarded the pro-democracy movement as the result of the spread of capitalism as an idea and as a practice. ${ }^{30}$

Why then did a sudden change take place after Deng Xiaoping's nanxun? Two important and subtle factors can be identified. First, the political interests of the regime were reconstructed in the early 1990s. Second, the reconstruction of political interests created an ideological room for capitalism as a way to reorganize society. In the early 1990s, a 
serious political legitimacy crisis hit the CCP, following the crackdown of the 1989 pro-democracy movement and the collapse of communism in the Soviet Union and East European countries. Initially, regime survival became the highest priority, and consequently, the leadership tightened its control by engaging in both political and economic rectification. Nevertheless, Chinese leaders, especially Deng Xiaoping, also realized that the fall of the Soviet Union and the collapse of East European communism was mainly due to the failure of economic development there. Therefore, the party needed to achieve radical economic growth if it wanted to avoid such a misfortune and rebuild its political legitimacy. Deng Xiaoping chose the path of initiating radical economic reforms. ${ }^{31}$

While the leadership decided to implement radical economic reform, it also began to build a new social order in accordance with the capitalist economic changes. Although the leadership tightened its political control in the aftermath of the 1989 movement, social demands for political reform were still prevalent. In order to transform popular passions for political interests to those for economic interests, the leadership had to provide social members with an economic 'exit.' While the crackdown of the 1989 movement showed social members the high cost of pursuing political interests, the opening of an economic 'exit' led them to realize that the shift from political interests to economic interests would be beneficial. In Hirschman's term, this is a strategy to transform people's 'public action' (demands for political reform) to 'private interest' (economic activities). ${ }^{32}$ The political significance of such an economic 'exit' motivated the leadership to de-ideologize capitalism as a means of economic expansion. This strategy resulted in almost a decade of rapid development and socio-political stability.

\section{A Rising Interest-based Social Order}

An interest-based social order is not a natural result of economic expansion, but was consciously pursued by the party leadership. What the leadership wants is not only economic expansion per se, but also the beneficial political consequences arising from rapid economic expansion. Economic expansion has generated enormous political benefits, not only because it has increased the regime's political legitimacy, but also because it has changed the space structure in the country. The conscious pursuit of economic expansion has led to the emergence of an interest-based social order, ${ }^{33}$ which in turn has resulted in the creation and expansion of a private arena. ${ }^{34}$ 
The rapid expansion of the private space is reflected in the decline of the state sector and the development of the non-state sector, as shown in Tables 1 and 2. From Table 1, we can see that the gross industrial output by the state-owned enterprises declined from 55 percent in 1990 to 27 percent in 1998, while that by individually owned enterprises increased from 5 percent to 16 percent during the same period. The nonstate sector has overwhelmingly surpassed the state sector.

\begin{tabular}{|c|c|c|c|c|c|}
\hline Year & $\begin{array}{c}\text { Total } \\
\%\end{array}$ & $\begin{array}{l}\text { State-owned } \\
\text { enterprises \% }\end{array}$ & $\begin{array}{c}\text { Collective-owned } \\
\text { enterprises } \%\end{array}$ & $\begin{array}{c}\text { Individually- } \\
\text { owned } \\
\text { enterprises \% }\end{array}$ & $\begin{array}{l}\text { Other types of } \\
\text { enterprises \% }\end{array}$ \\
\hline 1980 & 100 & 76.0 & 23.5 & 0 & 0.5 \\
\hline 1985 & 100 & 64.9 & 32.1 & 1.9 & 1.2 \\
\hline 1990 & 100 & 54.6 & 35.6 & 5.4 & 4.4 \\
\hline 1991 & 100 & 56.2 & 33.0 & 4.8 & 6.0 \\
\hline 1992 & 100 & 51.5 & 35.1 & 5.8 & 7.6 \\
\hline 1993 & 100 & 47.0 & 34.0 & 8.0 & 11.1 \\
\hline 1994 & 100 & 37.3 & 37.7 & 10.1 & 14.8 \\
\hline 1995 & 100 & 34.0 & 36.6 & 12.9 & 16.6 \\
\hline 1996 & 100 & 33.7 & 36.5 & 14.4 & 15.4 \\
\hline 1997 & 100 & 29.8 & 35.9 & 16.9 & 17.4 \\
\hline 1998 & 100 & 26.5 & 36.0 & 16.0 & 21.5 \\
\hline
\end{tabular}

Table 3 shows the economic significance of the private sector. The private sector consumed 4 percent of the total retail sales in 1996, and the figure increased to 13.5 percent in 1999. During the same period, the industrial and commercial taxes paid by the private sector in national total increased from 1 percent to 2.6 percent. The private sector has become even more important in revenue contribution at local levels. According to one calculation, as of the mid1990s, the private sector had contributed about 10 percent of the total tax revenue at the provincial level, 20 percent at the prefectural level, and 30 percent at the county level.$^{35}$ For instance, in 1996, the private sector in Zhejiang contributed 4.4 billion yuan industrial and commercial taxes, or 13.4 percent of the total industrial and commercial taxes in that province. In some rich areas, the private sector contributes township revenue as high as 60 percent. ${ }^{36}$

Nevertheless, it is worthwhile to point out that while the private sector has become increasingly important, its motivation to pay tax revenue to the state is low. Table 3 shows that in 1999, the private sector consumed 13.5 percent of retail sales of consumer goods, but its revenue contribution to the total industrial and commercial taxes was only 2.6 percent. Low incentive to contribute revenue is also reflected in Table 4. From 1986 to 1992, revenue contribution by 
TABLE 2: The Development of the Private Sector in China, 1989-97

\begin{tabular}{|c|c|c|c|c|c|c|c|c|}
\hline & \multicolumn{4}{|c|}{ Private enterprises* } & \multicolumn{4}{|c|}{ Individually owned and operated enterprises ${ }^{* *}$} \\
\hline & No. & $\begin{array}{c}\text { Change } \\
\%\end{array}$ & $\begin{array}{c}\text { Employees } \\
\text { (million) }\end{array}$ & $\begin{array}{c}\text { Change } \\
\%\end{array}$ & $\begin{array}{c}\text { No. } \\
\text { (million) }\end{array}$ & $\begin{array}{c}\text { Change } \\
\%\end{array}$ & $\begin{array}{c}\text { Employees } \\
(10,000)\end{array}$ & $\begin{array}{c}\text { Change } \\
\%\end{array}$ \\
\hline 1989 & 90,581 & & 1.6 & & 12.5 & & 19.4 & \\
\hline 1990 & 98,141 & 8.3 & 1.7 & 3.7 & 13.3 & 6.5 & 20.9 & 7.8 \\
\hline 1991 & 107,843 & 9.9 & 1.8 & 8.2 & 14.2 & 6.7 & 22.6 & 7.9 \\
\hline 1992 & 139,633 & 29.5 & 2.3 & 26.1 & 15.3 & 8.3 & 24.7 & 9.3 \\
\hline 1993 & 237,919 & 70.4 & 3.7 & 60.8 & 17.7 & 15.2 & 29.4 & 19.1 \\
\hline 1994 & 432,240 & 81.7 & 6.5 & 73.3 & 21.9 & 23.8 & 37.8 & 28.5 \\
\hline 1995 & 654,531 & 51.4 & 9.6 & 47.5 & 25.3 & 15.6 & 46.2 & 22.2 \\
\hline 1996 & 819,252 & 25.2 & 11.7 & 22.2 & 27.1 & 7.0 & 50.2 & 8.7 \\
\hline 1997 & 960,726 & 17.3 & 13.5 & 15.2 & 28.5 & 5.4 & 54.4 & 8.5 \\
\hline 1998 & 1200,978 & 25.0 & 17.1 & 26.7 & n.a & n.a & n.a & n.a \\
\hline 1999 & 1508,857 & 25.6 & 20.2 & 18.8 & & & & \\
\hline \multicolumn{9}{|c|}{$\begin{array}{l}\text { * Refers to those with more than eight employees } \\
* * \text { Refers to those with less than eight employees } \\
\text { Note: Annual percentage change in number of employees may not be exact due to rounding off } \\
\text { of figures. } \\
\text { Sources: Adapted from Zhang Houyi and Ming Zhili (eds.), Zhongguo siying qiye fazhan baogao } \\
\text { 1978-1998 [A Report on the Development of Private Enterprises in China, 1978-1998] (Beijing: } \\
\text { Shehui kexue wenxuan chubanshe, 1999), pp. 60, 66; Zhongguo siying jingji nianjian [The } \\
\text { Yea rbook of Private Businesses in China, 2000] (Beijing: Huawen chubanshe, 2000), p. } 402 .\end{array}$} \\
\hline
\end{tabular}

the private sector was largely in accordance with its share of the total national industrial output. After 1992, the gap between the two widened dramatically. For instance, in 1998, while the private sector contributed only 7 percent of the total national budgetary revenue, it accounted for more than 17 percent of the total industrial output. ${ }^{37}$

The rapid expansion of private space has undermined, or even destroyed, the old ideologically constructed social order. The household registration system has faced gradual erosion since the introduction of a market economy in the 1980s. With basic daily necessities available through the market, the state was no longer able effectively to control population movement from rural to urban areas, from interior to coastal areas, and from small to large cities. The system was further undermined by intensive economic competition among regions. To attract

\begin{tabular}{|c|c|c|c|c|}
\hline \multicolumn{5}{|c|}{$\begin{array}{l}\text { TABLE 3: The Economic Significance of the Private Sector in China, } \\
\text { 1996-99 }\end{array}$} \\
\hline & 1996 & 1997 & 1998 & 1999 \\
\hline $\begin{array}{l}\text { Percentage of goods consumed by the private } \\
\text { sector in total retail sales }\end{array}$ & 4.1 & 6.8 & 10.5 & 13.5 \\
\hline $\begin{array}{l}\text { Percentage of industrial and commercial taxes } \\
\text { by the private sector in total industrial and } \\
\text { commercial taxes }\end{array}$ & 1.11 & 1.31 & 2.14 & 2.63 \\
\hline
\end{tabular}


TABLE 4: Revenue Contribution by the Private Enterprises, and Individually Owned Enterprises, 1986-98*

\begin{tabular}{|c|c|c|c|c|}
\hline & $\begin{array}{l}\text { Tax revenue } \\
\text { (billion, yuan) }\end{array}$ & $\begin{array}{c}\text { \% Total budge tary } \\
\text { revenue }\end{array}$ & $\%$ Total GDP & $\begin{array}{c}\% \text { Total industrial } \\
\text { output }\end{array}$ \\
\hline 1986 & 4.93 & 2.32 & 0.48 & 2.76 \\
\hline 1990 & 14.57 & 4.96 & 0.79 & 5.39 \\
\hline 1991 & 17.42 & 5.53 & 0.81 & 4.83 \\
\hline 1992 & 20.33 & 5.84 & 0.76 & 5.80 \\
\hline 1993 & 29.34 & 6.75 & 0.85 & 7.98 \\
\hline 1994 & 37.03 & 7.10 & 0.79 & 10.09 \\
\hline 1995 & 42.96 & 6.88 & 0.73 & 12.86 \\
\hline 1996 & 46.96 & 6.34 & 0.69 & 15.48 \\
\hline 1997 & 56.79 & 6.56 & 0.76 & 17.92 \\
\hline 1998 & 70.00 & 7.09 & 0.89 & 17.11 \\
\hline \multicolumn{5}{|c|}{$\begin{array}{l}\text { *'Private enterprise' and 'individually owned enterprise' are two different concepts in China } \\
\text { the former refers to those enterprises that have more than eight employees, while the latter } \\
\text { refers to those enterprises that have less than eight employees. } \\
\text { Source: Hu Angang (ed.), Zhongguo tiaozhan fubai [China: Fighting against Corruption], } \\
\text { (Hangzhou: Zhejiang renmin chubanshe, 2001), p. 50. }\end{array}$} \\
\hline
\end{tabular}

talented people, many cities have substantially relaxed the original registrations required for the employment of non-local residents. ${ }^{38}$

In Russia and some other East European communist states, the collapse of the ideologically constructed social order had resulted in socioeconomic chaos. But this is not the case in China. The creation and expansion of a private arena is what distinguishes China from the fate of the other communist states. Although the expanding private space is confined to the non-political arena, it is politically significant. First of all, it provides social members with an 'exit' from the public arena. Without such a private exit, social members would have to struggle for what they want in a highly politicized public arena. Since there was no private arena, they would have to fight to win in this public arena; otherwise, they would lose everything. This would undoubtedly intensify political conflicts among social members. Therefore, the expansion of a private arena reduces greatly the intensity of political conflicts, and thus the political burden of the party and the government.

Second, the existence of a private arena makes it possible for citizens to remain apolitical, if they do not want to be involved in politics. In an ideologically constructed society, political indifference is possible, but politically risky. Since all economic benefits are distributed through political means, social members had to engage in politics. In contrast, an interest-based social order not only allows people to pay less attention to politics, but also encourages them to devote themselves whole- 
heartedly to economic activities. In other words, political indifference is no longer risky, and politically indifferent citizens can obtain their basic necessities through the market.

Third, with the dawn of an interest-based social order, China's economic development has gained a spontaneous and natural momentum. In an ideologically constructed social order, any political change would inevitably affect economic activities. But in an interest-based social order, economic activities are less affected by political changes. An interest-based social order has an inherent capability to resist the impact of political changes. Government intervention in economic activities is reduced, but economic development continues. This in turn increases the legitimacy of the government, though it is now less responsible for economic development.

\section{Political Order Affected}

The rise of an interest-based social order is beneficial for the legitimacy of the party-state at an early stage. Nonetheless, a continuously expanding social order has come to produce enormous unexpected political consequences that affect the existing political order. In other words, an interest-based social order has gradually undermined the existing political order and thus created pressure for interest representation.

With rapid economic expansion, the private arena has become more profitable than the public arena. The nascent interest-based social order has thus attracted not only social members, but also party cadres and government officials. This is especially true in the period after Deng Xiaoping's southern tour. Party cadres and government officials were allowed, even encouraged, by the reformist leadership to turn to business. This soon resulted in a nationwide wave of xiahai (literally 'plunging into the sea'). ${ }^{39}$ As shown in Table 5, in 1992, party cadres and government officials were the second largest group (25.5 percent) who established private businesses, following household-business owners (38.2 percent). By the mid-1990s, as shown in Table 6, they had become the largest group in private enterprises.

By encouraging party cadres and government officials to turn to business, the party leadership aimed to reduce their political resistance to radical economic reforms. To a great degree, this goal was realized. But it was achieved at great costs. First of all, many talents 'exited' from the state to the private arena, especially those who had promoted China's market reform. Since they had been involved in new forms of economic activities, they were more knowledgeable than others on how to make 
TABLE 5: Background of Owners of Private Enterprises in China (percent)

\begin{tabular}{|c|c|c|c|c|}
\hline Original Position & $\begin{array}{c}\text { Business } \\
\text { established before } \\
1988\end{array}$ & $\begin{array}{c}\text { Business } \\
\text { established } \\
1989-92\end{array}$ & $\begin{array}{c}\text { Business } \\
\text { established } \\
1992\end{array}$ & $\begin{array}{c}\text { Percentage } \\
\text { share }\end{array}$ \\
\hline Professionals & 1.9 & 4.3 & 4.9 & 4.6 \\
\hline Party cadres & 19.8 & 16.0 & 25.5 & 25.5 \\
\hline Workers & 13.2 & 8.6 & 10.8 & 10.7 \\
\hline Peasants & 20.8 & 17.9 & 15.8 & 16.7 \\
\hline $\begin{array}{l}\text { Household- } \\
\text { business owners }\end{array}$ & 35.8 & 46.3 & 36.9 & 38.2 \\
\hline Others & 8.5 & 6.8 & 6.1 & 6.5 \\
\hline Total & 100 & 100 & 100 & 100 \\
\hline
\end{tabular}

Source: Zhang Houyi and Ming Zhili (eds.), Zhongguo siying qiye fazhan baogao 1978-1998, p. 153.

profits through an emerging market. Such an 'exit' indeed weakened the reformist forces in the country. Second, party cadres and government officials were given opportunities to utilize their public power to gain private economic benefits. For example, party cadres and government officials have attempted to build up their connections (guanxi) with the private sector. In a survey conducted in 1993, when private entrepreneurs were asked to name their closest friends, the distribution was as follows: professionals (16.6 percent), cadres in the government sector (24.4 percent); cadres in SOEs (18 percent), workers (1.3 percent), farmers (3.7 percent),

TABLE 6: Background of Owners of Private Enterprises in China (percent)

\begin{tabular}{|c|c|c|c|c|c|c|}
\hline & \multicolumn{3}{|c|}{1993 survey } & \multicolumn{3}{|c|}{1995 survey } \\
\hline & $\begin{array}{l}\text { Urban } \\
\text { areas }\end{array}$ & $\begin{array}{l}\text { Rural } \\
\text { areas }\end{array}$ & $\begin{array}{c}\text { Percentage } \\
\text { share }\end{array}$ & $\begin{array}{l}\text { Urban } \\
\text { areas }\end{array}$ & $\begin{array}{l}\text { Rural } \\
\text { areas }\end{array}$ & $\begin{array}{c}\text { Percentage } \\
\text { share }\end{array}$ \\
\hline Professionals & 3.9 & 1.6 & 3.3 & 4.1 & 2.3 & 3.3 \\
\hline $\begin{array}{l}\text { Cadres in urban } \\
\text { state \& collective } \\
\text { sectors }\end{array}$ & 43.2 & 16.6 & 36.3 & 33.2 & 11.8 & 24.0 \\
\hline Rural cadres & 4.1 & 16.9 & 7.5 & 3.5 & 11.2 & 6.8 \\
\hline $\begin{array}{l}\text { Cadres in the non- } \\
\text { state sectors }\end{array}$ & 11.2 & 17.9 & 13.0 & 11.0 & 17.9 & 14.0 \\
\hline Peasants & 4.4 & 16.3 & 7.5 & 6.3 & 17.3 & 11.0 \\
\hline Workers & 22.9 & 11.4 & 19.7 & 21.7 & 17.5 & 19.9 \\
\hline $\begin{array}{l}\text { Small-scale } \\
\text { individual business } \\
\text { owners }\end{array}$ & 8.8 & 18.2 & 11.2 & 15.8 & 18.1 & 16.8 \\
\hline No occupation & 1.5 & 1.0 & 1.4 & 4.5 & 3.8 & 4.2 \\
\hline
\end{tabular}


specialized artisans (6.4 percent), staff in the service sector (9.5 percent), and small enterprise owners (8.9), and others (2.9)..$^{40}$ According to the study, to build their connections with the private sector, party cadres and government officials aimed to: (a) gain economic benefits for themselves and their family members; (b) search for opportunities to xiahai, i.e., to leave the government sector and turn to business; and (c) seek political support from the private sector due to its increasing political importance. ${ }^{41}$

When public power is used for economic benefits, corruption becomes inevitable and increasingly serious. While in the old days political loyalty was the most important standard used to evaluate the political achievements of party cadres and government officials, 'money' has now come to replace political loyalty. Corruption has undermined not only the effectiveness of the government, but also popular confidence in the government. Shoring up political legitimacy has thus become once again a serious challenge for the party and the government.

The Chinese state has played an extremely important role in pushing the process of economic transformation. But the close linkages between the government and businesses have led to widespread corruption among party cadres and government officials. Corruption has become increasingly serious since the early 1990s, as shown in Table 7. Between 1993 and 2000, the number of cases investigated and handled by discipline inspection and procuratorial organs throughout the country increased 9 percent annually, and the number of officials given party and administrative disciplinary punishments went up 12 percent. Between 1990 and 1998, procuratorial organs nationwide accepted and handled more than 1.1 million corruption cases, of which over 500,000 cases were placed

TABLE 7: The Development of Corruption among Leading Cadres in the 1990s

\begin{tabular}{|c|c|c|c|c|c|c|c|c|}
\hline & & 1993 & 1994 & 1995 & 1996 & 1997 & $\begin{array}{c}\text { Jan-Sept } \\
1998\end{array}$ & 1999 \\
\hline \multirow{3}{*}{$\begin{array}{l}\text { Punished by party } \\
\& \text { gov. disciplines }\end{array}$} & Provincial level & 6 & 17 & 24 & 23 & 7 & 10 & 17 \\
\hline & Prefectural level & 205 & 309 & 429 & 467 & 576 & 219 & 327 \\
\hline & County level & 2,793 & 3,528 & 4,880 & 5,868 & 6,585 & 2,955 & 4,029 \\
\hline \multirow{3}{*}{$\begin{array}{l}\text { Investigated by } \\
\text { procuratorial } \\
\text { organs }\end{array}$} & Provincial level & 1 & 1 & 2 & 5 & 3 & 3 & 3 \\
\hline & Prefectural level & 7 & 88 & 145 & 143 & 148 & 85 & 136 \\
\hline & County level & 1,141 & 1,826 & 2,306 & 2,551 & 2,426 & 1,462 & 2,200 \\
\hline \multirow{3}{*}{ Sentenced by law } & Provincial level & & 1 & & 1 & 5 & 2 & 2 \\
\hline & Prefectural level & 7 & 28 & 35 & 43 & 58 & 30 & 65 \\
\hline & County level & 69 & 202 & 396 & 364 & 403 & 271 & 367 \\
\hline
\end{tabular}

Source: The Research Group of the Department of Organization, the CCP Central Committee (ed.), 2000-2001 Zhongguo diaocha baogao: xin xingshi xia renmin neibu maodun yanjiu [China Investigation Report, 2000-2001: Studies of Contradictions within the People under New Conditions], (Beijing: Zhongyang bianyi chubanshe, 2001), p. 86. 
on file for investigation and prosecution. More than 600,000 offenders were involved. ${ }^{42}$ From January to August 2000 alone, the procuratorates throughout the country prosecuted 23,464 criminal cases involving graft and embezzlement. ${ }^{43}$ The 2000 Corruption Perceptions Index of Transparency International ranked China as 63rd among 90 countries. ${ }^{44}$

Since the early 1990s, the Chinese state has initiated a series of anticorruption measures. Nevertheless, corruption is still rampant. Even Premier Zhu Rongii had to admit, in his Work Report to the National People's Congress in March 2000, that 'the emergence and spread of corruption and undesirable practices have not been brought under control. ${ }^{45}$ Corruption has caused social and political instability. It also aroused people's ire against the party's inability to ensure fairness and cast doubts on its legitimacy to rule the country.

All these economic and social problems have further eroded social morale. Ordinary citizens see the abundance of wealth and greed of party cadres and government officials, and find it difficult to rationalize why they should hold back. Gradually, they no longer regard the system in which they live as being fair to them. Meanwhile, government officials at different levels have also found that it is increasingly difficult to maintain a sense of morality and social community among both urban and rural residents. Moreover, as corruption becomes rampant among party cadres and government officials, crime has also become widespread among ordinary citizens. ${ }^{46}$ Robbery and armed assault, which were unthinkable during Mao's time, have become a part of daily life.

Various surveys show that since the early 1990s, 'serious corruption committed by government officials' and 'public disorder' were among the issues of concern among ordinary citizens in China. ${ }^{47}$ When the government becomes corrupt and public order becomes problematic, people tend to become discontented and anxious. According to a 1998 survey, nearly 93 percent of the respondents did not regard China as a country ruled by law. When asked what they would do if conflict or disputes with others occurred, 74.7 percent indicated that they would turn to legal means for a resolution. Nevertheless, they also believed that such means would be ineffective since power was still above the law in China, so they would appeal through other non-legal means. About 49 percent said that they would seek help from the media, and 24.7 percent would turn to individual leaders. Furthermore, about 16 percent of the people would turn to some form of collective action for justice such as petition, demonstration, and collective visit to higher authorities for their intervention (shang fang). ${ }^{48}$ 


\begin{tabular}{|l|c|c|}
\hline \multicolumn{3}{|c|}{ TABLE 8: Key Political Factors that Affect Private Businesses (percent) } \\
\hline & 1995 & 1997 \\
\hline Legal protection of property rights & 5.1 & 4.1 \\
\hline Government propaganda & 5.0 & 6.0 \\
\hline Taxation policy & 18.8 & n.a. \\
\hline Credit policy & 31.8 & 27.2 \\
\hline Government macro-economic adjustment & 23.6 & 17.9 \\
\hline Industrial and commercial management & 2.6 & 31.9 \\
\hline Household system & 0.6 & 5.2 \\
\hline Ownership & 5.0 & 0.4 \\
\hline Others & 7.5 & 7.2 \\
\hline Total & 100 & 100 \\
\hline Source: Zhang Houyi and Ming Zhili (eds.), Zhongguo siying qiye fazhan baogao 1978-1998, p.150 \\
\hline
\end{tabular}

The most serious threat is that the party is increasingly facing pressure to incorporate newly rising social forces into its political order. The nascent social order has a strong justification to request that its voice be heard since government policies have an impact on its rise and fall. Table 8 shows the results of two nationwide surveys conducted in 1995 and 1997 respectively. We can see that taxation policy, credit policy, government macro-economic adjustment, and industrial and commercial management, among others, have been the most important political factors affecting their business activities. More and more, private businesspeople expect to participate in policy-making or at least have some input in policy-making. Moreover, the private sector has been affected not only by relevant government policies, but also by various forms of social and political practices prevalent in China. As shown in Table 9, 'exchange between power and money,' 'worsening public order' and 'arbitrary collection of fees, fines and levies' have been regarded as the factors that have had the most serious impact on private businesses. To change such social and political practices is no easy task and would require the political participation of private business persons.

TABLE 9: Social Problems with most Serious Negative Impact on Private Businesses (percent)

\begin{tabular}{|l|c|c|}
\hline & 1995 & 1997 \\
\hline Unjust income distribution & 5.1 & 9.9 \\
\hline Exchange between power and money & 37.3 & 37.6 \\
\hline Worsening public order & 20.6 & 41.1 \\
\hline Arbitrary fees, arbitrary fines, and arbitrary levies & 31.4 & 6.3 \\
\hline Business involvement of government and military in businesses & 2.6 & 3.9 \\
\hline Others & 8.1 & 1.3 \\
\hline Total & 100 & 100 \\
\hline
\end{tabular}

Source: Zhang Houyi and Ming Zhili (eds.), Zhongguo siying qiye fazhan baogao 1978-1998, p. 148. 
Indeed, private entrepreneurs have been making great efforts to participate in the political process, especially in local politics. No systematic national statistics are available to show the degree of political participation by private businesspeople. But as shown in Table 10, a rapid

TABLE 10: Representatives from the Private Sector in Political Organizations

\begin{tabular}{|c|c|c|c|}
\hline Year & $\begin{array}{c}\text { Representatives in the } \\
\text { People's Congress at the } \\
\text { county level and above }\end{array}$ & $\begin{array}{c}\text { Representatives in the } \\
\text { CPPCC at the county } \\
\text { level and above* }\end{array}$ & $\begin{array}{c}\text { Representatives' } \\
\text { mass organizations** }\end{array}$ \\
\hline 1990 & 5,114 & 7,238 & 4,603 \\
\hline 1994 & 7,296 & 11,721 & 7,671 \\
\hline Increase & $42 \%$ & $62 \%$ & $67 \%$ \\
\hline * CPPCC: The Chinese People's Political Consultative Conference \\
** Such as the Communist Youth League and the Women's Federation \\
Source: Zhonghua gongshang shibao [China Industrial and Commercial Daily], 29 April 1996 \\
\hline
\end{tabular}

expansion of their involvement in local politics took place in the early 1990s. According to a survey conducted in 1993, on average, each private entrepreneur had membership in 2.75 organizations such as private enterprise associations, guilds, different democratic parties, Youth League, and even the Chinese Communist Party. Almost 84 percent of private entrepreneurs argued that it was imperative to establish their own organizations. ${ }^{49}$ Another means for private entrepreneurs to influence China's political process was for them to join the CCP. According to various surveys, more and more private entrepreneurs have become party members. In 1993, among all private entrepreneurs, 13 percent were CCP members, and this figure was 17 percent in 1995, and 16.6 percent in 1997. In 2000, this figure increased to almost 20 percent, far higher than other social groups such as workers and farmers. ${ }^{50}$

Political participation by private entrepreneurs is still extremely limited at the national level. For example, only 46 out of more than 2,000 representatives of the 9th Chinese People's Political Consultative Conference

TABLE 11: Self-evaluation by Private Business People of Their Economic, Social and Political Status

\begin{tabular}{|c|c|c|c|}
\hline & Economic status & Social status & Political status \\
\hline 1993 & 4.5 & 4.0 & 4.6 \\
\hline 1995 & 4.5 & 4.2 & 5.1 \\
\hline 1997 & 4.7 & 4.6 & 5.7 \\
\hline $\begin{array}{l}\text { The highest score: } 1.0 \\
\text { The lowest score: } 10.0 \\
\text { Source: Zhang Houyi and Ming Zhili (eds.), Zhongguo siying qiye fazhan baogao 1978-1998, p. 163. }\end{array}$
\end{tabular}


(CPPCC) in 1998 were private businesspeople. ${ }^{51}$ A low degree of political participation indeed has caused dissatisfaction among this sector. As shown in Table 11, while self-evaluation by private businesspeople about their economic and social status has been consistent, that of their political status has deteriorated. It is worthwhile to note that their self-evaluation for political status was lowest in 1997, the year the private sector was formally legalized by China's Constitution. ${ }^{52}$

\section{Accommodation and Representation}

The response of the CCP is to co-opt rising social forces into the regime. Since the southern tour, the new leadership has made great efforts not only to legitimize and institutionalize the emerging interest-based social order, but also to search for a proper political order which will be compatible with this emerging social order. While the party-state has attempted, albeit without success, to incorporate some social groups into the regime, it still remains intolerant of any direct democratic challenge, which became apparent towards the end of the 1990s, as exemplified by the attempts of Chinese pro-democracy activists to organize an opposition party. In the last few months of 1998, the preparatory committees of China's Democracy Party were established in 23 out of China's 31 provinces and major cities. Applications to register the new party were made in 14 provinces and cities. ${ }^{53}$ As long as the party-state 'refuses' to address the democratic challenge head-on, it will stay irrelevant to newly emerging democratic forces. The CCP leadership is intolerant of direct political challenges mounted by social groups, but attempts have been made to accommodate newly rising social forces. This can be shown by changes introduced into the country's Constitution.

Constitutional changes in China could mean two things, first, a replacement of the existing constitution with a new one (1954-82), and second, making amendments to the Constitution (1982-99). When the political situation changes, the old Constitution is likely to be replaced by a new one. Thus the 1975 Constitution is called the 'Cultural Revolution Constitution,' the 1978 Constitution the 'Four-Modernization Constitution,' and the 1982 Constitution the 'Reform and Open-Door Constitution.' Similarly, each revision of the Constitution was motivated by strong political concerns and heavily influenced by the leadership's intention to adjust the political system to changing situations. It is worthwhile to briefly examine the constitutional changes related to the private sector.

According to the 1954 Constitution, the first one in the history of People's Republic, China's political system was led by the working class as 
its leading class and the worker-peasant alliance as its foundation (Article 1). Regarding the economic system, the Constitution decreed that the state would aim at eliminating the exploitative system and building a socialist system. While the state sector should be in a dominant position, other sectors such as collective cooperatives, individually owned enterprises, private capitalist economy, and state capitalism were allowed to co-exist (Articles 5 and 10). Furthermore, the Constitution also provided protection to citizens' ownership of legal incomes, savings, properties and other forms of productive materials (Article 11), and protection to the right of inheritance of private properties (Article 12). Meanwhile, the state would collect and even confiscate land and other forms of productive materials in accordance with laws and regulations in order to meet the needs of public interests (Article 13), and everyone was prohibited from utilizing his/her private properties to undermine public interests (Article 14). The Constitution also declared that public properties were sacred and inviolable, and it was every citizen's duty to protect public properties (Article 101).

Many waves of political movements such as the Anti-Rightist Movement and the Cultural Revolution almost completely nullified the 1954 Constitution. In 1975, the party leadership under the 'Gang of Four' drew up a new Constitution. The 1975 Constitution formally nullified many articles regarding citizens' rights in the 1954 Constitution, and added some articles to meet the political needs of that time. To support the party became the citizens' rights, although citizens were also granted the right to rebel. The revised Constitution was reduced to 30 articles from the original 106.

After the death of Mao Zedong and the overthrow of the Gang of Four in 1976, the CCP leadership under Hua Guofeng decided to make a constitutional revision in 1978. Though the Constitution was expanded to 60 articles by restoring some articles of the 1954 Constitution, it was still based on the 1975 Constitution. In accordance with political changes in train at that time, the use of material incentives to promote the fourmodernizations was legalized.

After Deng Xiaoping returned to power, the CCP leadership passed an entirely new constitution, i.e., the 1982 Constitution. The new Constitution restored almost all the articles of the 1954 Constitution. New ones were added (from 106 articles in 1954 to 138) to meet new political and economic needs. Though the 1982 Constitution still emphasized that the state sector had to be dominant in China's economy, it recognized that individually engaged economic activities in both rural and urban areas were complementary to the state 
sector (Article 11). What was later called the private enterprise (which employed more than eight workers) was not legalized.

In 1988, the first constitutional amendment was made. Two significant changes were made regarding China's economic system. First, one paragraph was added to Article 11:

The state allows the private economy to exist and develop within the legal boundary. The private economy is a complement to the socialist public economy. The state protects legal rights and interests of the private economy, provides it with leadership, supervision and management (Article 11, para. 3).

Second, para. 4 of Article 10 was revised: The state recognized that 'land use right can be transferred in accordance with legal regulations.' This change was significant since it meant that the state legalized employment, capital accumulation, land commercialization and other newly rising economic activities. Five years later, in 1993, the second constitutional amendment was made. The 1993 amendment gave up the planned economic system, and formally declared that a socialist market economy was to be established.

The official confirmation of the market economy led to serious criticisms against capitalistic development by the Leftists, both old and new, in the mid-1990s. Despite controversies, the leadership decided to press on. The 15th Party Congress in 1997 further pointed to how a market economy could be rooted in China, and declared a programme of partial privatization of state-owned enterprises. Further, based on the 1993 amendment, the Second Session of the 9th National People's Congress (NPC) in 1999 made a constitutional amendment, which, for the first time since the establishment of the People's Republic, provided constitutional protection for the private economy. ${ }^{54}$

While it will take a long time for the CCP to establish an interestbased political order, all these constitutional changes in the 1990s show that the party leadership has made great efforts to adjust China's political system not only to promote further economic development, but also to accommodate capitalist economic institutions. In February 2000, Jiang Zemin raised a new concept of sange daibiao (literally 'Three Representations'). According to this concept, the CCP represents the 'most advanced mode of productive force, the most advanced culture, and the interests of the majority of the population. ${ }^{.55}$ The 'Three Representations' theory is undoubtedly the clearest sign yet of the CCP's affirmation of the non-state sector in the economy. More importantly, it also shows that the CCP has begun to consider how the interests of newly 
rising classes or social groups can be represented. As discussed at the beginning of this paper, the CCP leadership has also legitimized party membership of private entrepreneurs or capitalists. All these changes have been warmly received by the private sector, and are widely regarded as a symbol of the CCP's transformation from a communist party to one containing some social democratic elements.

\section{Transformation and Political risks}

What the CCP has done provides clear indications that the party is jettisoning its past ideological rigidity by willingly embracing rising economic and social elites. The party's initiative is apparently motivated by pragmatic political considerations. First, admitting private entrepreneurs is a means for the party to adapt itself to China's changing political and social realities. As mentioned earlier, many private entrepreneurs are already party members. What the party leadership proposes to do today is formally to endorse their party membership while allowing others to join as new members. Second, by so doing, the leadership wants to expand the party's social base in order to revitalize itself. Over the years, the capitalist mode of economic development has radically changed China's class structure. With the decline of the political and ideological importance of workers and peasants, the party has to embrace the rising new elites, from industrialists and international businessmen to property magnates and 'dotcom' venture capitalists, in order to stay socially relevant. China today has 60 million registered stock and share buyers, roughly equal to the total party membership.

Politically, the party's initiative to embrace these new social elites or new economic interest groups is clearly calculated to bolster its oneparty domination. Mao could depend on class struggle and mass movements to govern China, and he could count on the support of millions of poor peasants and workers. China was then a backward agricultural economy, with peasants accounting for 80 percent of the total labour force. Today, China is a growing industrial economy, with peasants constituting less than 50 percent of the labour force and many of them not even full-time farmers.

Specifically, the party leadership simply cannot rule China today by mass political mobilization as Mao once did, since the party's original power base has fast eroded. China is rapidly developing into a modern society, with 130 million hand-phones and close to 30 million Internet users. The economy is increasingly integrated with international capitalism on account of China's growing foreign trade, foreign investment 
and foreign tourism. The populace is also becoming increasingly literate, especially in urban areas.

Furthermore, state governance in China is not yet highly institutionalized, and the rule of law not firmly rooted. For the party effectively to rule such a vast and diverse country without sound democratic foundations, it is all the more crucial for the party leadership to build up a broad social consensus and a coalition of various interests. Clearly, the party cannot exclude the 'outstanding elements' of society from the private sector. For China's emerging political order to remain viable, the party has to be socially more broad-based.

However, the party will have to bear some long-term costs for admitting capitalists and professionals. Leftist critics have warned that the recruitment of the bourgeoisie into the party will inevitably create more corruption in the party, making it easier for the 'money for power' phenomenon to take place. Some critics have even suggested that capitalists may eventually take over the party's leadership. ${ }^{56}$

This is actually already happening in many party branches in the rural areas where businessmen are reported to have used their financial power to manipulate local elections or simply take over local party branches. Suffice it to say that with capitalists inside the party, they will certainly act as potential catalysts to quicken the transformation of the party. Judging by the way Chinese society is evolving, there is a real possibility that the party, in admitting capitalists, has also let in the Trojan horse.

This top-down transformation is not without any political risks. The most serious challenge for the CCP is to determine whose interests it should represent. During Mao Zedong's time, the CCP was genuinely a revolutionary party with its members drawn overwhelmingly from workers and peasants, who constituted 83 percent of the total membership in 1956. But this figure dropped to 52 percent in 1994. ${ }^{57}$ After his return to power, Deng started what may be called a 'technocratic movement,' replacing revolutionary cadres in party leadership positions with technocrats, with an essential proportion increasingly coming from the non-state sector. ${ }^{58}$ When the party associates itself with capitalists, workers and farmers tend to feel alienated. Scholars have found that SOE workers and rural farmers are rapidly becoming the two biggest losers of capitalistic development. ${ }^{59}$ Rapidly growing new leftists are fearful that the party might favour these new entrepreneur-members at the expense of its traditional clients, i.e., workers and farmers. While in the past the party protected the workers, the present may see the party colluding 
with the entrepreneur to clamp down on the workers. They argue that being wealthier and wielding greater influence, these capitalists would exert an unhealthy bias in the formulation of party policies. Worse, the close links between the CCP and the capitalists would breed new types of cronyism and corruption. New leftists thus have called on workers and farmers with democratic mechanisms to articulate their interests.

\section{Can 'Voice' Mechanisms be Established?}

So, the key question is: What choices does the party-state face in transforming itself into a democratic mechanism? This question can be answered in different ways, but in terms of the representation of class interests, three options can be identified.

\section{Multi-party system}

This is the alternative that most scholars have called for. It has been argued that democracy means a multi-party system. Without political competition among parties, there will be no democracy. For the CCP, this choice is to have parties outside the party (dangwai youdang). Demands for establishing opposition parties were there and became apparent towards the end of the 1990s, as exemplified by the attempt of Chinese pro-democracy activists to organize an opposition party. In a few months of 1998, the preparatory committees of China's Democracy Party were established in 23 out of China's 31 provinces and major cities. Applications to register the new party were made in 14 provinces and cities. ${ }^{60}$

The unfolding of this event also shows that different opinions existed among CCP leaders regarding opposition parties. A multi-party system undoubtedly is ideal, but realistically speaking, it is less likely. Except for dissidents inside and outside China, the majority of the population are not demanding a multi-party system. Democratization characterized by the emergence of a multi-party system in Russia, Taiwan and Indonesia has not enabled the regimes there to improve people's living standards. Instead, social decay and economic chaos have become prevalent there. The majority is more likely to choose other alternatives, if they exist. Furthermore, the party-state favours a top-down approach. The leadership is intolerant of direct political challenges mounted by social groups, although attempts have been made to accommodate newly rising social groups. To a great degree, democracy is not an option decided by social groups. 


\section{Factional politics within the party}

More feasible than a multi-party system is the option to legitimize and institutionalize factions within the party (dangnei youpai). Like elsewhere, factions existed within the CCP. Even under Maoist coercive rule, factional struggles never disappeared among top leaders. Certainly, under Mao, factions were unlikely to be institutionalized. Since the passing of the Deng-centred generation leadership, factional politics has been institutionalized to some degree and many organization-based factions have been formed, such as the party, the National People's Congress and the State Council. Other factions have also co-existed such as the Shanghai Clique, the Qinghua Clique (those who graduated from Qinghua University), the Tuanpai (officials related to the Communist Youth League), the Taizidang (the princelings), and so forth. These factions have their own interests and identity, their own ways for interest articulation.

All these factions will not help in establishing 'voice' mechanisms for different social groups. To materialize interest articulation, the leadership has, first, to legalize factional politics, and second, to address class interests. Without the legitimization of factional politics, factional competition can only be engaged informally. The legitimization and institutionalization of factions help make the political process transparent. Social classes therefore will be able to identify their interests with certain factions. Certainly, more important is that the party has to allow different factions to represent the interests of different social classes. Organization-based factions only represent the interests of these organizations, not those of the social classes. Once factions are legitimized, these factions will appeal to different social classes in their competition for political power. Power competition will further push the party to establish inter-party democratic mechanisms since without such mechanisms, the party will fall apart. While factions enable the party to represent different social interests, inter-party democracy enables the party to remain united.

\section{Reforming the existing system}

The most feasible but less effective option in representing different social interests is to reform the existing political system. The Chinese political system is not without any advantages. The problem is that the leadership never considers the issue of interest representation. Many mechanisms are actually available for interest representation. Among others, three reforms have to be made. First, the People's Congress is the most feasible mechanism for different social classes to articulate their interests. To achieve this goal, reforms have to be introduced to transform the People's Congress into a real institution for people's rep- 
resentatives. Needless to say, people's representatives have to be selected and elected by people. ${ }^{61}$

Second, the People's Consultative Conference (PCC) system has to be re-organized and indeed re-politicized. Before the People's Congress was established in 1954, the PCC played an important political role in representing the interests of different political parties and functional groups. China did not have a multi-party system after 1949. The PCC, instead of political parties, played the role of interest articulation and integration. This model used to inspire the first Indonesian President Sukarno in designing Indonesia's political system. In order to avoid political chaos and instability caused by intensive competition among enormous parties, Indonesia established GOLKAR (functional groups) for interest articulation and representation. ${ }^{62}$ In China, after 1954, the PCC was sidelined. Even after the reform began, the PCC is still an institution for retired government officials and social elites. Today, the PCC is only a forum for these representatives: it has the right to discuss the issues, but no right to vote. To a great degree, it is a political organization without any political significance. To revive the PCC, it has to be granted the right to vote. Furthermore, it has to go back to its previous role of representing different functional groups (social interests). Its relationship with the People's Congress has also to be sorted out.

Third, at the next level, civil society and social organizations have to adjust their functions. Throughout the reform period, social groups have mushroomed..$^{63}$ But at present, all those social organizations are not able to aggregate and articulate social interests, even their own interests. The development of social organizations has been extremely uneven. There are more economic and social organizations are than political ones, and more urban organizations than rural ones. Furthermore, all these social organizations are highly dependent on the party-state. To empower them to articulate social interests, the party-state has to, first, grant them a greater degree of autonomy, and second, allow them to form their own class identity.

\section{Conclusion}

Interest representation requires a systematic transformation of the $\mathrm{CCP}$ dominated Chinese political system. The CCP has claimed that it would represent the interests of the majority of people. This is easier said than done. Moreover, interest representation requires institutions for interest aggregation and articulation, and aggregating and articulating diverse social interests requires political participation. In the long haul, 
democratization appears to be the only option for the CCP to achieve interest representation and build long-term stability.

The party leadership may genuinely believe that it is doing what it takes to strengthen the party-state by broadening its social base. As the party metamorphosizes, there is still the nagging question of whether it is prepared to democratize itself. No precedent exists to guide the CCP through such unchartered waters and the risks of failure are enormous. If the party falters, the breakup of the world's most populous nation is a possibility. While Jiang may have taken a courageous step forward, the onus is on $\mathrm{Hu}$ Jintao and other leaders to see the democratization process through. The jury is still out on whether the CCP will succeed in this endeavour.

Dr. Zheng Yongnian is Senior Research Fellow at the East Asian Institute of National University of Singapore.

\section{Notes}

1 Jiang Zemin, 'Jiang Zemin zai qingzhu Zhongguo gongchandang chengli bashi zhounian dahui shang de jianghua' [Jiang Zemin's Speech at the Conference Celebrating the 80th Anniversary of the Chinese Communist Party, 1 July 2001), Renmin ribao [People's Daily] , 2 July 2001. Also 'Entrepreneurs from Non-Public Sector Hail Jiang's Speech,' Beijing Review, 9 August 2001.

2 Ming pao, 23 July 2001.

3 Lin Yanzhi, 'Gongchandang yao lingdao he jiayu xin zichan jieji'[The CCP Must Lead and Control the New Bourgeoisie], Zhengli de zhuiqiu [The Seeking of Truth], no. 5, (2001), pp. 211.

4 Zhang Dejiang, 'Yao mingque siying qiyezhu buneng rudang' [To Make Clear that Private Entrepreneurs Cannot Join the Party ], Zhengli de zhuiqiu, no. 5.(2001), p. 28. Zhang's original paper was published in Dang de jianshe [Party Constructing], no. 4, (2000).

5 'Showdown of Ideologies,' South China Morning Post, 15 August 2001; and 'Party Closes Leftist Journal that Opposed Jiang,' South China Morning Post, 14 August 2001.

6 'Dissenting Leftist Websites Taken off from Internet,' South China Morning Post, 3 September 2001).

7 'Jiang urged the armed forces to thoroughly understand the July 1 Speech,' Ming pao, 3 September 2001.

8 This paper focuses primarily on Hirschman's definition, see Albert O. Hirschman, The Passions and the Interests: Political Arguments for Capitalism before its Triumph (Princeton, NJ: Princeton University Press, 1977); and Albert O.Hirschman, "The Concept of Interest: from Euphemism to Tautology' and 'Rival Views of Market Society,' in Albert O. Hirschman, Rival Views of Market Society and Other Recent Essays (Cambridge, MA: Harvard University Press, 1992), pp. 35-55, 105-41.

9 Hirschman, 'The Concept of Interest,' p. 35.

10 Ibid., p. 43.

11 Ibid., p. 36.

12 Ibid., p. 42.

13 Ibid., p. 43. 
14 Cited in Hirschman, Rival Views of Market Society and Other Recent Essays, p. 107. For a discussion of Montesquieu's ideas, also seeStephen Rosow, 'Commerce, Power and Justice: Montesquieu on International Politics,' Review of Politics, vol. 46, no. 3, (1984), pp. 346-67.

15 Hirschman, The Passions and the Interests, p. 87.

16 Ibid., pp. 89-93.

17 Adam Smith, Wealth of Nations (Oxford: Oxford University Press, 1976), pp. 443, 456.

18 Similar ideas are also expressed by Milton Friedman, Capitalism and Freedom (Chicago: University of Chicago Press, 1982).

19 Franz Schurmann, Ideology and Organization in Communist China (Berkeley, CA: University of California Press, 1968), p. 1.

20 For example, Tang Tsou, The Cultural Revolution and Post-Mao Reforms: A Historical Perspective (Chicago: The University of Chicago Press, 1986).

21 Tiejun Cheng and Mark Selden, 'The Construction of Spatial Hierarchies: China's Hukou and Danwei System,' in Timothy Cheek and Tony Saich (eds.), New Perspectives on State Socialism in China (Armonk, NY: M. E. Sharpe, 1977), pp. 23-50.

22 All organizations in urban China where people worked such as enterprises, retail shops, hospitals, schools, civil associations, government organs were called 'danwei.' Roughly speaking, three types of danwei can be identified: 1) enterprise units, including all units engaged in making profit; 2) non-profit units, including scientific, educational, professional, cultural, athletic and healthcare organizations; and 3) administrative units or governmental organs. For a discussion of the danwei system, see Xiaobo Lü and Elizabeth J. Perry (eds.), Danwei: The Changing Chinese Workplace in Historical and Comparative Perspective (Armond, NY: M. E. Sharpe, 1997), pp. 3-7.

23 For a discussion of 'conscription society,' see Gregory J. Kasza, The Conscription Society: Administered Mass Organization (New Haven, CT: Yale University Press, 1995).

24 Vivienne Shue, 'State Power and Social Organization in China,' in Joel S. Migdal, Atul Kohli and Vivienne Shue (eds.), State Power and Social Forces: Domination and Transformation in the Third World (New York, NY: Cambridge University Press, 1994), pp. 65-88.

25 On 18 December 1978, the Chinese Communist Party held the historic Third Plenum of the 11th Party Congress in Beijing. The Third Plenum shifted the party's priority from Maoist class struggle to economic modernization. Officially, the Third Plenum marks the beginning of China's market-style economic reform and the open-door policy.

26 For a discussion of China's economic reform and development in the 1980s, see Barry Naughton, Growing out of the Plan: Chinese Economic Reform 1978-1993(New York: Cambridge University Press, 1996).

27 Wang Gungwu, The Chinese Way: China's Position in International Relations (Oslo:Scandinavian University Press, 1995).

28 For a discussion of different perceptions on socialism and capitalism, see Yan Sun, The Chinese Reassessment of Socialism, 1976-1992 (Princeton, NJ: Princeton University Press, 1995).

29 Wang Gungwu discussed why the leadership used the term 'socialist market economy' rather than capitalism, see Wang, The Chinese Way, part one.

30 Yan Sun, The Chinese Reassessment of Socialism, 1976-1992.

31 Deng Xiaoping, 'Zai Wuchang, Shenzhen, Zhuhai, Shanghai dengdi de tanhua yaodian,' [Main Points in the Speeches Made in Wuchang, Shenzhen, Zhuhai, and Shanghai,' 18 January-21 February 1992], in Deng, Deng Xiaoping wenxuan [Selected Works of Deng Xiaoping], vol. 3 (Beijing: Renmin chubanshe, 1993), p. 379.

32 Hirschman, Shifting Involvements: Private Interest and Public Action (Princeton, NJ: Princeton University Press, 1982).

33 This is not the place for a full discussion of this rising interest-based social order. But it is worth noting that terms associated with economic interests such as 'interest' (or 'interests') and 'class' have been increasingly used by scholars in China to analyse the Chinese society 
since Deng's Nanxun. See, Zhu Guanglei etal. (eds.), Dangdai Zhongguo shehuigejiecengfenxi [An Analysis of Social Strata in Contemporary China] (Tianjin: Tianjin renmin chubanshe, 1998); Liang Xiaosheng, Zhongguo shehui ge jieceng fenxi [An Analysis of Social Strata in China] (Beijing: Jingii ribao chubanshe, 1998); Lu Xueyi and Jing Tiankuai (eds.), Zhuanxing zhong de Zhongguo shehui [Chinese Society in Transition], (Ha'erbin: Heilongiang renmin chubanshe, 1994); Qin Shaoxiang and Jia Ting, Shehui xin qunti tanmi: Zhongguo siqing qiyezhu jieceng [A Study of ANew Social Group: China's Private Enterprise Class] (Beijing: Zhongguo fazhan chubanshe, 1993).

34 For discussions of increasing autonomy of social groups, see Wang Ying, et al. (eds.), Shehui zhongiian ceng: gaige yu Zhongguo de shetuan zuzhi [Intermediate Social Strata: the Reform and Social Groups in China] (Beijing: Zhongguo fazhan chubanshe, 1993); Deborah S. Davis et al. (eds.), Urban Spaces in Contemporary China: the Potential for Autonomy and Community in post-Mao China (Washington, DC: Woodrow Wilson Center Press /Cambridge and New York: Cambridge University Press, 1995); Timothy Brook and B. Michael Frolic (eds.), Civil Society in China (Armonk, NY: M. E. Sharpe, 1997); Gordon White, Jude Howell and Shang Xiaoyuan, In Search of Civil Society: Market Reform and Social Change in Contemporary China (Oxford: Oxford University Press, 1996).

35 Li Qiang, 'Guanyu siyingjingji de ruogan ziliao' [Data on the Private Economy], Zhengli de zhuiqiu no. 5 (2001), pp. 18-19.

36 Ibid., p. 19.

$37 \mathrm{Hu}$ Angang (ed.), Zhongguo tiaozhan fubai [China: Fighting against Corruption], (Hangzhou: Zhejiang renmin chubanshe, 2001), p. 49.

38 Hein Mallee, 'China's Household Registration System under Reform,' in Alan Hunter and Kim-kwong Chan (eds.), Protestantism in Contemporary China (Cambridge: Cambridge University Press, 1993), pp. 10-16.

39 For a description, see John Wong, 'The Xia Hai Phenomenon in China,' Ritsumeikan Journal of International Relations and Area Studies, vol. 6 (March 1994), pp. 1-10.

40 Li Qiang, 'Guanyu siyingjingji de ruogan ziliao,' p. 23.

41 Cited in ibid., pp. 23-24.

42 'Major Corruption Cases,' Beijing Review, 22 May 2000, p. 14.

43 Renmin ribao, 15 September 2000, p. 1.

44 Zou Keyuan, 'Why China's Rampant Corruption Cannot be Checked by Laws Alone,' EAI Background Brief No. 74, East Asian Institute, National University of Singapore, (2 November 2000).

45 China Daily, 6 March 2000.

46 Børge Bakken, 'State Control and Social Control in China,' in Kjeld Erik Brødsgaard and Susan Young (eds.), State Capacity in Japan, Taiwan, China and Vietnam (Oxford: Oxford University Press, 2000), pp. 185-202.

47 The annual survey reports are organized by the Institute of Sociology of the Chinese Academy of Social Sciences; see its annual report, Ru Xin etal. (eds.), Shehuilanpishu:Zhongguo shehui xingshi fenxi yu yuce [Social Bluebook: Analysis and Forecast of Social Situation in China], various issues. (Beijing: Shehui kexue wenxian chubanshe).

48 Wang Chunguang, '1997-1998 nian: Zhongguo shehui wending zhuangkuang de diaocha' [A Survey on Social Stability in 1997-1998], in Ru Xin et al. (eds.), Shehui lanpishu 1998 [Social Bluebook 1998] (Beijing: Shehui kexue wenxian chubanshe, 1998), p. 127.

49 Cited in Li Qiang, 'Guanyu siyingjingji,' p. 27.

50 Ibid., p. 26.

51 Jiang Nanyang, 'Lun siying qiyezhu de zhengzhi cenyu' [Political Participation by the Owners of Private Businesses], in Zhang Houyi and Ming Zhili (eds.), Zhongguo siying qiye fazhan baogao 1978-1998 [A Report of the Development of Private Enterprises in China, 1978-1998] (Beijing: Shehui kexue wenxuan chubanshe, 1999), pp. 103-17. 
52 Keyuan Zou and Yongnian Zheng, 'China's Third Constitutional Amendment: an Assessment,' in A. J. De Roo and R. W. Jagtenberg (eds.), Yearbook Law and Legal Practice in East Asia, vol. 4, 1999 (The Hague, London and Boston: Kluwer Law International, 2000), pp. 29-42.

53 John Pomfret, 'Why "Beijing Spring" Cooled: Dissidents Overstepped,' International Herald Tribune, 4 January 1999, pp. 1, 7.

54 For a discussion of this constitutional amendment, see Zou and Zheng, 'China's Third Constitutional Amendment: An Assessment.'

55 The Xinhua News Agency, 'Jiang Zemin tongzhi zai quanguo dangxiao gongzuo huiyi shang de jianghua,' 9 June 2000 [Comrade Jiang Zemin's Talk in National Party Schools Working Conference, 9 June 2000], Renmin ribao, 17 July 2000.

56 Lin Yanzhi, 'Gongchandang yao lingdao he jiayu xin zichan jieji.'

57 Ignatius Wibowo, 'Party Recruitment and the Future of the Chinese Communist Party,' EAI Background Brief No. 101, East Asian Institute, National University of Singapore, 7 September 2001.

58 Hong Yung Lee, From Revolutionary Cadres to Party Technocrats in Socialist China (Berkeley: University of California Press, 1991); and Cheng Li and David Bachman, 'Localism, Elitism, and Immobilism: Elite Formation and Social Change in Post-Mao China,' World Politics, vol. 42, no. 1, (October 1989), pp. 64-94.

59 Shaoguang Wang, 'The Social and Political Implications of China's WTO Membership,' Journal of Contemporary China, vol. 9, no. 25, (2000), p. 380.

60 John Pomfret, 'Why "Beijing Spring" Cooled.'

61 For some recent discussions of China's People's Congress system, see Kevin O'Brien, 'Chinese People's Congresses and Legislative Embeddedness: Understanding Early Organizational Development,' Comparative Political Studies, vol. 27, no. 4, (1994), pp. 80-107; O’Brien, 'Institutionalizing Chinese Legislatures: Trade-offs between Autonomy and Capacity,' Legislative Studies Quarterly, vol. 23, no. 1, (1998), pp. 91-108; and Murray Scot Tanner, The Politics of Lawmaking in Post-Mao China: Institutions, Processes and Democratic Perspectives (New York: Oxford University Press, 1998).

62 David Reeve, GOLKAR of Indonesia: An Alternative to the Party System (Singapore: Oxford University Press, 1985). It is worthwhile to note that the fall of the GOLKAR was not because of its institutional design, but because of the lack of internal democracy within the organization.

63 For example, Gordon White, Jude Howell and Shang Xiaoyuan, In Search of Civil Society. 